\title{
STRATEGI PETANI DALAM MENGHADAPI KEKURANGAN AIR: STUDI KASUS DI DAERAH IRIGASI WANIR, KECAMATAN CIPARAY, KABUPATEN BANDUNG
}

\author{
Hardian Eko Nurseto ${ }^{1}$ dan Adi Nugraha ${ }^{2}$ \\ ${ }^{1}$ Departemen Antropologi, Fakultas Ilmu Sosial dan Ilmu Politik Universitas Padjadjaran \\ ${ }^{2}$ Departemen Sosial Ekonomi Pertanian, Fakultas Pertanian Universitas Padjadjaran
}

\begin{abstract}
ABSTRAK
Ketersediaan air irigasi sangat penting dalam pertanian.Namun, sifat dan jumlah pasokan air yang tak terduga, ketika musim kemarau air sulit untuk didapat dan dapat mengancam pertumbuhan, terkadang di musim hujan jumlah air melebihi batas hingga menimbulkan banjir dan menghancurkan tanaman padi. Untuk itu diperlukan berbagai strategi untuk menyiasati dan menjamin ketersediaan air guna mempertahankan produktifitas pertanian. Penelitian ini bermaksud menggambarkan bagaimana petani di Dusun Leles Desa Mekarsari Kecamatan Ciparay Kabupaten Bandung bekerjasama dalam menjamin ketersediaan air irigasi.

Penelitian dilakukan dengan menggunakan pendekatan kualitatif dengan pemaparan deskriptif yang bertujuan menggambarkan bagaimana petani-petani di Dusun Leles Desa Mekarsari Kecamatan Ciparay Kabupaten Bandung membuat strategi-strategi dalam mengelola irigasi. Hasil yang didapat, Petani mengembangkan organisasi irigasi untuk meneglola air irigasi melalu Mitra Cai. Petani bekerjasama melakukan nganir cai, dan pompanisasi. Selain itu juga petani mengaktifkan hubungan-hubungan kekerabatan untuk mendapatkan akses pada air irigasi.
\end{abstract}

Kata kunci: irigasi, strategi petani, mitra cai

\begin{abstract}
The availability and access to water is very vital to agriculture. However, both of these are often unpredictable in some parts of Indonesia, especially in locations which has 'bowl' geographical characteristic such as Ciparay District, Bandung Regency, West Java. This is due to lack of infrastructure and water management system. During the drought, the water is so scarce while during rainy season, the water overflows. This condition poses threats to surrounding farmlands. Therefore, a proper water management system is needed. This paper aims to identify how do farmers in Mekarsari Village, Ciparay work together in assuring the availability and their access to water. The study was a qualitative study which was designed to provide in-depth information in order to describe the phenomenon. The results show that there is a self-organized organization, which was formed by farmers to arrange the water usage in the region. The farmers are bound to mitra cai organization, organizing themselves to do nganir cai (looking for water sources) and distribute the water. Aside of that, the farmers also enhance collegial relationships in the process, reducing the risks of social dispute.
\end{abstract}

Keywords: irrigation, farmers' strategy, mitra cai

\section{PENDAHULUAN}

Penelitian ini adalah tentang stategi petani $^{2}$ dalam pemenuhan air irigasi di Daerah

\footnotetext{
${ }^{2}$ Wolf (1985:2) membedakan petani menurut kegiatan usahanya kedalam dua kelompok: Pertama, pengusaha pertanian (farmer) yaitu pengelola perusahaan pertanian dengan mengkombinasikan faktor-faktor produksi yang diupayakan dengan sejumlah modal kemudian hasil produksi dijual ke pasar untuk memperoleh keuntungan. Kedua, petani pedesaan (peasant) yaitu petani yang bercocok tanam di daerah pedesaan, ia tidak melakukan usaha pertanian sebagai sebuah perusahaan bisnis tetapi
}

Irigasi Wanir. Penelitian ini bermaksud menggambarkan bagaimana petani di Dusun Leles Desa Mekarsari Kecamatan Ciparay Kabupaten Bandung bekerjasama dalam menjamin ketersediaan air irigasi. Daerah Irigasi Wanir Berada pada daerah hulu subDAS Citarum yang mengairi lahan seluas

hanya mengelola lahan pertanian untuk memenuhi kebutuhan rumah tangga. Petani dalam penelitian ini merujuk pada definisi pertama "farmer". 
2062.5 ha dan tersebar dalam 14 desa di 3 kecamatan yaitu Kecamatan Pacet, Ciparay dan Majalaya. Selama periode kekeringan tahun 2014, debit air di bendungan Wanir mengalami penyusutan hingga 8366 1/detik (9160 1/detik menjadi 794 1/detik). Dampaknya adalah sekitar 1.500 hektar sawah di Pacet, Ciparay, dan Majalaya gagal panen (data sekunder Dinas pengairan Ciparay, 2015).

Saat musim kemarau panjang seringkali petani kesulitan mendapatkan air untuk mengaliri sawah mereka. Sementara, pada musim penghujan sungai Citarum seringkali meluap dan membanjiri pemukiman, serta menghancurkan tanaman padi mereka. Seperti yang diberitakan oleh Republika (25 juli 2015) "Ratusan hektare tanaman padi yang baru berusia di bawah sebulan di Kabupaten Bandung bagian selatan kekeringan dan mati akibat musim kemarau. "Kami harus menunggu hingga hujan turun, mungkin satu musim ini kami tidak bisa panen," kata Rahman, petani di Ciparay. Pasokan air dari irigasi Wanir tidak cukup untuk mengairi pesawahan di kawasan lahan sawah terluas di Kecamatan Ciparay tersebut."Sementara di musim penghujan Banjir melanda daerah tersebut, "Banjir yang melanda kabupaten Bandung selama beberapa hari terakhir, mengancam sedikitnya 365 hektar sawah akibat terendam. Pasalnya, tahun ini sawah yang terdampak banjir lebih besar dibandingkan tahun lalu yang mencapai 100 hektar.(Republika, 23 desember 2014)".

Ketersediaan air irigasi sangat penting dalam pertanian, karena air dapat memelihara stuktur tanah, menghambat dan menekan pertumbuhan gulma, mengatur tinggi rendahnya suhu tanah, dan membawa zat hara yang diperlukan oleh padi (Siregar, 1981:180). Idealnya air harus selalu tergenang selama kurang lebih 80 hari, dan 20 hari sisanya atau menjelang masa panen, sawah tidak memerlukan banyak air, bahkan harus dikeringkan (Hardjono, 1990). Namun, sifat dan jumlah pasokan air bisa tak terduga, ketika musim kemarau air sulit untuk didapat dan dapat mengancam pertumbuhan, dan terkadang di musim hujan jumlah air di saluran-saluran irigasi melewati batas dan menimbulkan banjir di petak-petak sawah, sehingga diperlukan berbagai strategi untuk menyiasati dan menjamin ketersediaan air guna mempertahankan produktifitas pertanian.
Pentingnya air irigasi bagi pertanian ini menjadikan "air" sebagai sumberdaya ${ }^{3}$ bagi petani dan mengandung arti bahwa adanya akses $^{4}$ terhadap sumber daya tersebut. Menurut Garret Hardin (1968, dalam Cousins 1995) apabila suatu sumberdaya itu open access atau tidak ada hak milik, sumber daya ini dapat dimiliki oleh setiap orang, dan hal ini sama saja dengan tidak dimiliki oleh siapapun, sehingga dapat dipakai secara bebas. Hal ini menurut Hardin akan menyebabkan "Tragedy of the Common" karena dengan akses terbuka (open access), akan terjadi over-eksploitasi sumber daya tersebut yang akan menyebabkan rusaknya sumberdaya tersebut. Hardin berpendapat bahwa akses terbuka akan mendorong aktor-aktor rasional untuk memaksimalkan penggunaan sumber daya yang pada akhirnya menyebabkan penurunan kualitas sumber daya tersebut. Namun, pendapat Hardin ini memunculkan kritik-kritik terhadapnya, karena model tragedy of the commons gagal membedakan antara akses terbuka dan kepemilikan komunal. Sementara Bromley dan Cernea (1989) menyatakan bahwa sumber daya bukan dilihat dari aspek fisik melainkan lebih pada unsur-unsur sosial yang terkait dalam pemanfaatan sumber daya tersebut. Hak pemanfaatan sumber daya ditentukan oleh anggota-anggota masyarakat beserta aturan -aturan yang telah disepakati. Bromley dan Carnea (1989) membagi kepemilikan dan pengaturan atas sumberdaya ke dalam empat kategori, yaitu open-acces (sumber daya yang berhak diakses oleh siapa

\footnotetext{
${ }^{3}$ Sumber daya adalah hasil dari pendapat, keinginan, keahlian, teknologi, modal, hukum, dan penataan secara institusi, seperti halnya kebiasaan politik. Apa yang menjadi sumber daya di suatu daerah mungkin hanya merupakan benda biasa saja di daerah lainnya (Mitchell,1989). Menurut Koning (2001: 262) sumber daya adalah aset, hak milik, produk, sarana-sarana, kepunyaan, kekayaan, nasib baik, kemakmuran dan modal. Sumber daya menurut Bromley ialah benefit stream atau aliran manfaat yang bisa diperoleh untuk mencapai tujuan. Secara umum Sumber daya merupakan "energi" yang bisa dimanfaatkan untuk mencapai tujuan. ${ }^{4}$ Akses (acces), di dalam The Concise Oxford Dictionary (1991: 7), dapat diartikan sebagai 1) sebuah jalan untuk mendatangkan atau mencapai sesuatu; 2) Hak atau kesempatan untuk menjangkau sesuatu; 3) merujuk pada kepentingan kelompok tertentu untuk mengerjakan sesuatu. Akses dapat dilihat secara kepemilikan atau penguasaan, bagaimana seseorang dapat mengakses yang menjadi miliknya dan bukan hak miliknya, atau bagaimana seseorang memiliki akses terhadap sesuatu yang bukan hak miliknya melalui penguasaan tanpa memilikinya.
} 
saja, misalnya udara, sinar matahari); commom property (sumberdaya milik bersama dan bukan milik pribadi) sumber daya ini hanya dapat diaksesoleh suatu kelompok masyarakat yang memiliki kekuasaan untuk mengunakan sumberdaya itu. Penggunaan sumberdaya tersebut diatur oleh sistem tertentu yang telah disepakati oleh masyarakat pengguna sumberdaya tersebut; state property (sumber daya milik negara) penggunaan sumber daya ini dikontrol langsung oleh negara, dan penggunaannya diautr oleh undang-undang dalam suatu negara, misalnya PLN (Perusahaan Listrik Negara); dan private property (sumber daya milik perorangan).

Sependapat dengan Bromley dan Carnea ternyata air irigasi tidaklah open access, Akses petani terhadap air irigasi tergantung pada banyak hal seperti, kepemilikan fisik, kedekatan tempat tinggal dengan sumber daya, dan hubunganhubungan sosial dengan pengambilan kebijakan pengelolaan air, inilah yang disebut modal. Mereka yang memiliki modal besar dan kontrol terhadap sumber daya, dalam artian memiliki teknologi dan sarana penyaluran air, dekat dengan sumber air atau bahkan menguasaianya, serta memiliki hubungan yang baik dengan pengaturan tingkat desa, hampir selalu mempunyai akses istimewa pada sumber daya air dan lebih mampu mengeksploitasinya (Benda-Beckman, Franz von dan Keebet Von Benda-Beckman, 2001: 41).

Petani sebagai pengelola lahan pertanian tentunya harus menjamin ketersediaan air pada petak-petak sawah mereka, agar proses produksi mereka berjalan dengan baik. Penyediaan dan pengendalian air merupakan faktor yang penting dalam penanaman padi. Air yang berlebih sama besar bahayanya dengan kekurangan air, dan untuk mengatasi permasalahan tersebut biasanya petani-petani memiliki mekanisme tertentu dalam pemenuhan kebutuhan atas air dengan mengacu pada waktu (Geertz, 1983:31). Penelitian Krishna (2000) di Rajathan India Selatan tentang keterlibatan penduduk desa dalam proyek penampungan air menunjukkan bahwa resiko kekurangan pasokan air dapat diselesaikan bersama-sama oleh warga desa. Salah satu upaya yang dilakukan untuk mengatasi masalah tersebut adalah berkerjasama dan menciptakan organisasi perkumpulan pemakai air. Jadi, berbagai upaya masyarakat dalam pengelolaan air dapat memunculkan tindakan-tindakan bersama dengan tujuan untuk menghindari dan menyelesaikan persoalan pasokan air.

Dalam menjamin ketersediaan air, terutama di Jawa, kelompok-kelompok petani membangun jaringan irigasi dengan memanfaatkan aliran sungai untukmengairi sawah-sawah mereka. Irigasi tidak dapat dilaksanakan secara perorangan,berbagai kegiatan keirigasian menuntut kerjasama diantara para petani yang bersangkutan. Petani-petani Jawa menjawab tuntutan itu dengan mengembangkan kerjasama yang erat diantara mereka, dan kerjasama yang erat itu menjadi landasan bagi munculnya peradaban khas masyarakat pertanian padi pada masa lampau, yaitu peradaban pengairan (hidraulic civilization) (Hutapea, 1996: x).

Pada masyarakat Bali, para petanipetani Bali mengembangkan teknologiirigasi yang kita kenal dengan nama Subak. Dalam organisasi Subak kerjasama antar petani juga menjadi faktor penting dalam penyediaan dan pendistribusian air irigasi. Ketika musim kemarau misalnya, dalam menghadapi kekurangan air mereka mengembangkan sistem pinjam-meminjam air antar Subak dalam satu aliran sungai. Penelitian Wayan Widia mengenai pengelolaan irigasi dalam kasusnya di Subak Agung Yeh Ho, TabananBali menjelaskan, bahwa dalam menghadapi kekurangan air pada musim kemarau Subak / Subak Gede saling meminjamkan air yang difasilitatori oleh Subak Agung dalam kasus ini adalah Subak Agung Yeh ho. Apabila ada Subak di hilir yang membutuhkan pinjaman air irigasi, maka mereka melapor kepada Pekaseh (pimpinan) Subak Agung yang kemudian akan meninjau Subak yang kekurangan air dan menghubungi Subak yang akan dipinjami air. Apabila persediaan air di Subak yang akan di pinjami air memungkinkan untuk dipinjam, maka penjaga pintu bendung akan mengalirkan air untuk Subak yang membutuhkan. Pada umumnya Subak di Hulu akan meminjamkan beberapa saat (beberapa hari) untuk dapat menolong temannya yang ada di daerah hilir (Widia, 1996, dalam Kurnia, 1997:247).

\footnotetext{
${ }^{5}$ Subak adalah lembaga yang mengatur dan menyalurkan air ke sawah-sawah untuk pertanian dan juga sangat efektif digunakan untuk memungut pajak tanah (Liefrinck dan Graeder dalam Shusila 1992:213-215).
} 
Pinjam-meminjam air ini bisa terjadi karena adanya kerjasama yang dilandasi oleh rasa persaudaraan dan rasa persatuan antara Subak-Subak di wilayah sungai Yeh Ho. Pertemuan-pertemuan mereka dalam upacara adat di pura-pura menjadi pemicu rasa persatuan dan persaudaraan diantara mereka. Namun, dalam telaah kesejarah yang dilakukan oleh S.R. Hutapea nilai-nilai kerjasama dan kebersamaan dalam pengelolaan irigasi pada periode Sebelum Penjajahan, Penjajahan, Republik Indonesia, mengalami gangguan yang semakin lama semakin serius sejak periode Penjajahan. Melemahnya kerjasama dan berkembangnya individualisme dalam pengelolaan irigasi terus berlanjut hingga ke masa pemerintahan Orde Baru. Pembentukan Perkumpulan Petani Pemakai Air (P3A) oleh pemerintah ternyata belum berfungsi dengan baik. Sistemnya yang seragam seluruh Indonesia, membuat petani menjadi pasif, dan hanya bergerak jika diperintah (Asnawi, 1996, dalam Hutapea, 1996: 43-45).

Pengelolaan sumber daya tentu saja berhubungan dengan pranata sosial, karena merupakan sistem yang menjadi wahana yang masyarakat dalam berinteraksi menurut polapola resmi. Pranata juga dapat dibatasi sebagai sistem norma khusus atau sistem aturan yang menata suatu ruang kajian tindakan berpola mantap guna memenuhi suatu keperluan khusus manusia dalam kehidupan bermasyarakat (Koentjaraningrat, 1992). Pranata sosial yang dikembangkan di berbagai tempat memenuhi fungsinya masing-masing secara khusus mengacu ke bentuk-bentuk persoalan yang dihadapi masyarakat. Van de Ven, misalnya menunjukan bagaimana pembagian waktu antar orang di dalam pengelolaan pertanian sebagai perwujudan solidaritas telah menyebabkan teratasinya persoalan pangan yang dihadapi penduduk (Van de Ven, 2000: 90, dalam Abdullah, 2004).

Dalam mengembangkan kerjasama, petani dapat menggunakan hubungan sosial dan jaringan sosial ${ }^{6}$ untuk menjamin

\footnotetext{
${ }^{6}$ Jaringan sosial adalah suatu rangkaian hubungan yang teratur atau hubungan sosial yang sama diantara individu-individu atau kelompok-kelompok (Granovetter dan Swedberg, 1992 dalam Damsar, 1997). Jaringan sosial terbentuk dalam masyarakat karena seseorang tidak dapat dan tidak mau berhubungan dengan semua orang yang ada, tetapi hubungannya selalu terbatas pada
}

ketersediaan air irigasi. Dalam masyarakat terdapat berbagai bentuk ikatan sosial yang berfungsi dengan baik, baik itu ikatan antarorang dalam berbagai bentuknya maupun ikatan antarkelompok. Ikatan ini membentuk suatu jaringan yang didasarkan pada berbagai prinsip.

Keluarga atau kerabat menjadi prinsip yang mendasar dalam berbagai transaksi sosial. Yang secara umum memiliki implikasi yang luas hingga keluar batas keluarga dan kerabat. Ikatan kekerabatan dapat mempengaruhi struktur akses yang bersifat ekonomi atau bersifat politik dalam usaha akumulasi kekayaan dan kekuasaan. Proses yang sama terjadi pada ikatan tempat tinggal dan ketetanggaan. Hubunganhubungan ketetanggaan yang diidealkan dalam suatu masyarakat dapat menjadi basis yang kuat didalam menggalang kekuatan serta mobilisasi dana dan tenaga kerja. Gotong royong misalnya, kegiatan ini sangat fungsional bagi pemecahan persoalansehari-hari yang dihadapi penduduk. Ikatan-ikatan semacam ini menjadi dasar adanya kohesi sosial dan solidaritas dalam masyarakat yang telah ditunjukan sebagai ikatan yang kuat untuk menghadapi berbagai persoalan dalam hidup manusia. Jaringan ini pada gilirannya akan menjadi sumber penting yang siap dimanfaatkan oleh anggota dalam mengakses berbagai kesempatan dan kepentingan. Pada saat mekanisme formal tidak mampu merespon kebutuhan penduduk, maka jaringan ini akan membentuk kekuatan yang telah teruji (Abdullah, 2004).

Ketidakstabilan pasokan air irigasi ini akan menimbulkan permasalan dalam mekanisme pembagian air. Hal tersebut akan membawa kita pada permasalahan bagaimana strategi yang dilakukan petani dalam rangka menjamin ketersedian air irigasi di petak-petak sawahnya. Penelitian ini ingin melihat bagaimana petani membuat kerjasama dalam pemenuhan kebutuhan air irigasi untuk menjamin ketersediaan air irigasi pada lahan pertaniannya, guna mempertahankan produktifitas pertanian mereka?

Kerangka Penelitian. Kestabilan pasokan air yang di setiap musim menjadi tantangan petani di Dusun Leles. Kelangkaan

sejumlah orang saja. Begitu juga, setiap orang belajar dari pengalamannya untuk masing-masing memilih untuk mengembangkan hubungan-hubungan sosial yang tersedia di masyarakatnya. (Suparlan, 1988). 
air di musim kemarau dan berlimpahnya air di musim penghujan merupakan masalah yang menuntut strategi ke arah kerjasama agar lahan garapan tetap berproduksi. Kerjasama antar pemakai saluran irigasi menjadi penting karena air tidak dimiliki satu orang saja dan resiko ketika pasokannya tidak stabil juga tidak ditanggung satu orang saja. Selain sebab alami seperti musim, faktor sosial juga menjadi penyebab ketidakstabilan (sifat air sebagai sumberdaya) yakni, akan diperebutkan jika pemakai lebih besar daripada yang tersedia. Persaingan menjadi sesuatu yang tidak bisa dihindari antar pengguna air irigasi. Pengaturan irigasi agar sesuai kebutuhan pada akhirnya menuntut strategi dari para penggunanya. Strategi yang dimaksud adalah hubungan-hubungan sosial dalam upaya untuk menjamin ketersediaan irigasi yang mewujud dalam bentuk kerjasama, baik antarorang atau antarkelompok. Oleh karena itu diasumsikan terdapat berbagai bentuk kerjasama yang dilakukan petani dalam mengatasi ketidakpastian pasokan air irigasi di musim kemarau dan penghujan. Bentuk-bentuk kerjasama bisa dilihat dari pembentukan organisasi irigasi, hubungan-hubungan sosial, jaringan sosial, dan koalisi-koalisi yang dilakukan petani dalam rangka menjamin ketersediaan air di petak-petak sawahnya. Pemenuhan kebutuhan air irigasi ini merupakan perwujudan dari strategi yang dilakukan petani untuk mengatasi kekurangan air.

Strategi pemenuhan air irigasi untuk produksi pertanian merupakan upaya petani dalam mengelola hubungan-hubungan sosial seperti kerjasama antar orang maupun antar kelompok dalam bentuk organisasi irigasi, hubungan-hubungan sosial, jaringan sosial, dan koalisi-koalisi yang ada. Pentingnya aspek sosial dalam pengelolaan irigasi ini perlu diketahui lebih mendalam mengingat strategi dalam pengelolaan sumberdaya berkaitan erat dengan kemampuan individu maupun kelompok dalam mengoptimalkan akses dan kontrol sumberdaya.

\section{METODE PENELITIAN}

Penelitian dilakukan dengan menggunakan pendekatan kualitatif dengan pemaparan deskriptif yang bertujuan menggambarkan bagaimana petani-petani di Dusun Leles Desa Mekarsari Kecamatan
Ciparay Kabupaten Bandung membuat strategi-strategi dalam mengelola irigasi. Satuan analisisnya adalah petani yang terhimpun dalam organisasi petani P3A/Mitra cai. Populasi penelitian ini adalah seluruh masyarakat petani sawah irigasi di Dusun Leles Desa Mekarsari Kecamatan Ciparay Kabupaten Bandung. Karena satuan analisis penelitian ini adalah petani baik individu maupun yang terhimpun dalam kelompok petani, maka teknik pengumpulan datanya adalah pengamatan terlibat (observasi partisipan), wawancara mendalam (deep interview), studi kepustakaan, dan dokumentasi.

Lokasi penelitian ini Dusun Leles Desa Mekarsari Kecamatan Ciparay Kabupaten Bandung Jawa Barat. Tempat ini dipilih karena Dusun Leles adalah daerah paling hilir dari Daerah Irigasi (DI) Wanir, sehingga terdapat permasalahan-permasalahan terkait ketidakstabilan pasokan air. Daerah Irigasi (DI) Wanir adalah salah satu dari 25 DI yang terdapat di Kabupaten Bandung. Daerah irigasi Wanir berada di wilayah kerja Cabang Dinas PU Pengairan wilayah VIII Ciparay dan cabang dinas PU Pengairan wilayah IX Majalaya, Dinas PU Pengairan kabupaten bandung. Suplai air utama Daerah Irigasi Wanir ini berasal dari sungai Citarum bagian hulu. Daerah Irigasi Wanir mengairi 14 desa di tiga kecamatan yaitu Kecamatan Pacet, Kecamatan Ciparay dan Kecamatan Majalaya. Daerah Irigasi ini memiliki bangunan utama berupa bendung, saluran primer sepanjang $1.25 \mathrm{~km}$ dan saluran sekunder sepanjang 27.22 $\mathrm{km}$. Terdapat tujuh buah saluran sekunder di Daerah Irigasi Wanir, yaitu Saluran sekunder Cibodas, Saluran sekunder Cikoneng, Saluran sekunder Cipeujeuh, Saluran sekunder Sukasadar, Saluran sekunder Pasir astana, Saluran sekunder Wangisagara, dan Saluran sekunder Rancakentang.

Penelitian ini khususnya dilakukan disebuah dusun di desa Mekarsari. Dusun ini bernama dusun Leles. Dusun leles merupakan satu dusun dari tiga dusun yang ada di desa Mekarsari. Dusun ini terletak dibagian paling barat dari wilayah desa Mekarsari dan berbatasan langsung dengan desa Magunggharja. Dusun leles ini meliputi RW 10, RW 11, RW 12, dan RW 13, yang dibatasi oleh batas alam yaitu sungai Cipadaulun dan sungai Cirasea. Dilihat dari topografinya, dusun ini merupakan hamparan tanah yang 
datar tanpa bukit yang dihiasi oleh talun bambu di sebelah utaranya.

\section{HASIL DAN PEMBAHASAN}

Pengguna Air Irigasi. Sektor pertanian merupakan pengguna air terbesar di Daerah Irigasi Wanir, karena Daerah Irigasi Wanir yang dibangun tahun 1965/1966 pada awalnya dibangun dengan tujuan untuk memajukan pertanian disekitar Pacet, Ciparay, dan Majalaya. Namun dengan semakin bertambahnya penduduk dan berkembangnya pembangunan berbagai sektor, pengguna air irigasi Wanir menjadi semakin bertambah. Saat ini yang menggunakan air irigasi Wanir antara lain petani, Industri tekstil disekitar Majalaya, dan kolam ikan arus deras.

Petani. Petani yang menggunakan air irigasi dari DI Wanir tersebar di seluruh wilayah pengairan DI Wanir, mulai dari kecamatan Pacet, Ciparay, dan Majalaya. Petani-petani di DI Wanir menggunakan air irigasi untuk mengairi sawah-sawah mereka. Petani merupakan pengguna air irigasi terbanyak di DI Wanir. Petani-petani tidak hanya menanam padi yang nanti berasnya dapat kita jumpai di pasar-pasar dan kita makan sebagai makanan pokok, walaupun sebenarnya komoditi utamanya adalah padi. beraneka ragam tanaman mereka tanam, mulai dari padi, beras merah, beras ketan, ketan hitam, kacang tanah, jagung, hingga sayur mayur seperti tomat dan sawi. Air irigasi merupakan faktor penting dalam mendukung pertanian mereka, karena tanpanya tanamantanaman tidak akan tumbuh.

Pengelolaan irigasi di DI Wanir Sejak tahun 2000, dikelola empat belas P3A (Perkumpulan Petani Pemakai Air) yang tersebar diseluruh daerah pengairan DI Wanir dengan satu GP3A (gabungan Perkumpulan Petani Pemakai Air) sebagai induknya. Dalam berita acara pembentukan GP3A ini disebutkan bahwa GP3A mengelola pengairan secara global dan mempunyai kewajiban mengelola jaringan irigasi pada tingkat primer dan sekunder, sedangkan $\mathrm{P} 3 \mathrm{~A}^{7}$ ikut mengelola jaringan irigasi pada tingkat tersier di petakpetak sawah daerah masing-masing, biasanya

\footnotetext{
${ }^{7}$ Perkumpulan petani pemakai air (P3A) adalah kelembagaan pengelolaan irigasi yang menjadi wadah petani pemakai air dalam suatu daerah pelayanan irigasi yang dibentuk oleh petani pemakai air sendiri secara demokratis, termasuk lembaga lokal pengelola irigasi (Peraturan Pemerintah nomor 20 tahun 2006).
}

P3A ada di tingkat desa. P3A ini berfungsi mengelola masyarakat tani untuk partisipatif dalam pengelolaan sistem irigasi di tingkat tersier yang diwujudkan mulai dari pemikiran, pengambilan keputusan, serta pelaksanaan kegiatan dalam pembangunan, peningkatan, operasi, pemeliharaan dan rehabilitasi. Partisipasi ini dapat diwujudkan dalam bentuk sumbangan pemikiran, gagasan, waktu, tenaga, material, dan dana.

\section{Kolam Ikan Arus Deras (running} water/raning). Running water adalah perikanan arus deras yang pengelolaannya membutuhkan debit air tinggi. Ikan yang dijadikan komoditas adalah ikan nila dan ikan mas. Running water mulai ada di DI Wanir pada awal tahun 90an, yang terdapat di daerah hulu yaitu di daerah Cipeujeuh dan Cikoneng. Lokasinya yang dekat dengan saluran sekunder membuat running water ini dengan mudah mengambil air langsung dari saluran sekunder. Air yang mengalir pada saluran irigasi langsung dibelokkan menuju kolamkolam ikan dengan cara membobol tembok saluran sekunder kemudian membuat pintu air untuk mengontrol debit air yang masuk ke kolam. Air irigasi yang masuk ke kolam selanjutnya dibuang melalui saluran pembuangan ke sungai. Pembuangan air dari kolam ke sungai ini menjadi masalah karena air tidak dapat digunakan kembali oleh petani. Ketinggian permukaan air yang lebih rendah dari permukaan sawah menyebabkan air tidak dapat mengalir ke sawah. Pembobolan saluran irigasi sekunder juga membuat berkurangnya debit air irigasi untuk pasokan air ke daerah hilir seperti daerah Leles.

Industri Tekstile. Terdapat sembilan perusahaan yang bergerak di industri tekstil dan pengolahan kain yang sumber airnya berasal dari air irigasi di DI Wanir. Industriindustri ini terletak di Kecamatan Majalaya, karena wilayah Kecamatan Ciparay dan Kecamatan Pacet tidak diperuntukkan bagi kawasan industri, melainkan sebagai kawasan pertanian, pemukiman dan pendidikan. Tercatat secara resmi terdapat sembilan industri tekstil yang mengunakan air irigasi dari saluran irigasi DI Wanir. Pemakaian air ini berkisar antara 0,5 1/detik sampai 10 1/detik setiap harinya untuk tiap industri. Perusahaanperusahaan tersebut berproduksi setiap harinya selama 24 jam dengan menggunakan air irigasi. 
Perusahaan-perusahaan tersebut mengambil air irigasi dengan membuat pintu pada saluran irigasi, dan membelokan air irigasi untuk ditampung di kolam penampungan. Kolam-kolam penampungan ini tidak berada di dalam kompleks pabrik. Kolam-kolam penampungan ini dibangun oleh masing-masing pabrik pada lokasi yang dekat dengan saluran sekunder dan berada didaerah tinggi. Kolam-kolam ini bisa berjarak hingga 2 Km jauhnya dari pabrik. Kolam-kolam penampungan air ini banyak ditemukan di desa Padaulun, dan Biru. Kolam penampungan yang dibuat oleh pabrik ini cukup besar, salah satunya kolam penampungan milik pabrik tekstile di desa Padaulun yang memiliki dua kolam penampungan, yang pertama berukuran $20 \mathrm{~m}$ X $8 \mathrm{~m}$ dengan kedalaman mencapai $4 \mathrm{~m}$, kemudian yang kolam kedua dengan ukuran lebih kecil 10 m X 10 m dengan kedalaman 4 $\mathrm{m}$. kolam-kolam ini dibuat besar dengan tujuan agar mampu menjaga pasokan air untuk proses produksi pabrik selama 24 jam.

Dalam menjaga pasokan air untuk produksinya pihak industri banyak memperkerjakan preman-preman atau orang yang ditakuti di daerah setempat untuk menjaga pasokan air dan kolam-kolam penampungan mereka. Para petani menyebut mereka dengan sebutan babah hideung. Pilihan pihak industri dengan memperkerjakan para preman datau babah hideung ini membuat petani segan untuk mengganggu pasokan air milik pabrik.

Perebutan air pada saluran irigasi sering terjadi pada musim kemarau, hal ini disebabkan karena debit air disungai citarum turun sehingga berpengaruh pada berkurangnya pasokan air irigasi bagi pengguna air irigasi. Perebutan air ini tidak hanya antar-petani dengan petani, tetapi perebutan air ini juga diramaikan oleh para pemilik running water atau perikanan arus deras dan Industri.

Terdapat beberapa persoalan yang dihadapi para pengguna air irigasi DI Wanir (petani, running water, dan industri) ini. Pertama akses pertani terhadap sumber daya air irigasi terganggu dengan adanya kedua sektor lain yang memiliki modal dan teknologi yang lebih tinggi dalam mengakses sumberdaya air. Padalah menurut pasal 8 ayat 2 UU. No. 11 Tahun 1974 prioritas penggunaan air adalah untuk kebutuhan domestik, pertanian, dan ketenagaan (industri). Berdasarkan undangundang ini dapat disimpulkan bahwa industri berada dalam prioritas terakhir untuk penggunaan air. Tetapi, dalam kenyataannya di DI Wanir, industri dan running water (yang juga merupakan sektor ketenagaan) justru memperoleh akses yang lebih baik terhadap air irigasi. Pemilik usaha running water memiliki akses yang baik terhadap air irigasi, karena modal dan hubungan sosial dengan aparat desa yang mereka miliki. Sedangkan, pada sektor Industri terdapat teknologi yang lebih tinggi dibandingkan para petani, dengan membangun kolam penampungan air di daerah hulu dan saluran air yang menghubungkan kolam penampungan dengan pabrik. Dalam BendaBeckman (2001) dinyatakan bahwa mereka yang memiliki modal besar dan kontrol terhadap sumber daya, dalam artian memiliki teknologi dan sarana penyaluran air, dekat dengan sumber air atau bahkan menguasaianya, serta memiliki hubungan yang baik dengan pengaturan tingkat desa, hampir selalu mempunyai akses istimewa pada sumber daya air dan lebih mampu mengeksploitasinya. Hal ini terlihat dari kemudahan akses terhadap air yang dimiliki oleh running water dan industri yang memiliki modal lebih besar daripada petani. Lalu baggaimana strategi petani dalam menghadapi kekurangan air untuk sawah mereka?

Strategi Petani. Dusun Leles berada di daerah paling hilir dari daerah irigasi Wanir. Kondisi ini menyebabkan pasokan air irigasi di daerah ini tidak stabil. Berdasarkan hasil penelitian dapat disimpulkan beberapa hal yang menjadi hambatan kelancaran pasokan air irigasi di dusun Leles, terutama di musim kemarau antara lain, rusaknya pintu-pintu air, mengeringnya tanah pada saluran irigasi kuarter (solokan) membuat air yang mengalir lebih dulu terserap kedalam tanah sebelum mengalir ke petak-petak sawah, dan perebutan air dengan pengguna air irigasi (petani lain, industri dan pemilik kolam ikan arus deras) di daerah girang atau hulu.

Untuk mengatasi masalah diatas, petani membuat sebuah organisasi P3A/Mitra cai yang kemudian dikuatkan oleh Surat Keputusan (SK) Gubernur. P3A/Mitra cai ini terbentuk sekitar 1980-an dengan nama P3A/Mitra Cai "Harapan I". Bentuk-bentuk pengelolaan yang dilakukan mitra cai dalam upaya menyediakan air irigasi berbeda-beda 
dalam satu tahunnya. Perbedaan pengelolaan ini dikarenakan adanya perbedaan musim (kemarau-hujan) yang berpengaruh pada stok air yang tersedia di saluran irigasi.

Pengelolaan mitra cai untuk menjamin pasokan air irigasi pada musim kemarau ialah, Pembagian dan penjadwalan penggunaan air irigasi dengan daerah lain, nganir cai dan pompanisasi. Untuk mengatasi masalah ini, para petani, mitra cai, dan industri bekerjasama membuat bendungan di saluran pembuangan air dari industri. Sementara pada awal musim hujan, untuk bersiap-siap menghadapi debit air yang bertambah petani berkerja bakti memperbaiki saluran-saluran irigasi tersier. Perbaikan saluran irigasi oleh petani ini berupa pembersihan saluran dari sampah, peninggian galengan, memperdalam parit, ngarucug, dan menyumbat kuluwung.

Dalam melaksanakan pengelolaan irigasi P3A/Mitra cai membutuhkan biaya untuk operasionalnya. Biaya ini tidak ditanggung oleh P3A/Mitra cai, dalam rapat anggota telah disepakati bahwa petani yang menjadi anggota P3A/Mitra cai tetapi tidak menjadi pengurus akan membayarkan sejumlah uang atau gabah setiap kali panen untuk menutupi pengeluaran-pengeluaran P3A/Mitra cai. Besarnya iuran yang dikeluarkan petani ini berbeda-beda, tergantung dari luas lahan garapannya dan juga musim tanamnya. Besarnya iuran yang harus dikeluarkan petani musim kemarau sebesar $40 \mathrm{~kg}$ gabah/100 tumbak setiap kali panen, dan untuk musim hujan tidak ada ketentuan harus membayar iuran tetapi petani diharapkan membayar iuran seihklasnya kepada pengurus mitra cai. Pembayaran biasanya dilakukan di sawah ketika sedang memanen padi.

Strategi kerjasama petani dalam pengelolaan air sangatlah penting, karena tanpa itu petani tidak dapat menjamin ketersediaan air irigasi mereka, dan akan berpengaruh terhadap hasil panen mereka. Letak geografis Dusun Leles yang berada di hilir irigasi Wanir kurang menguntungkan petani di daerah tersebut. Lamanya waktu air irigasi untuk sampai ke daerah tersebut dan banyaknya hambatan-hambatan yang ditemui selama air mengalir, menyebabkan pasokan air di Dusun Leles tidak stabil. Selain itu, kurangnya modal dan kekuasaan petani dalam mengakses sumber daya air irigasi menjadi faktor tambahan yang menghambat pasokan air. Masalah-masalah di atas menunjukan bahwa, petani di Dusun Leles perlu melakukan strategi kerjasama di antara mereka dengan cara nganir cai, pompanisasi, iuran petani di setiap akhir musim panen, dan kerjasama di tingkat keluarga.

Usaha nganir cai yang dilakukan petani di Dusun Leles mampu menyelesaikan masalah pasokan air, namun pada musim kemarau panjang - ketika air sungai Citarum surut dan tidak bisa mengisi bendungan Wanir - usaha nganir cai menjadi percuma karena tidak ada air yang bisa dimanfaatkan. Untuk mengatasi masalah ini petani melalui Mitra cai mengembangkan teknologi pengairan dengan menyedot air dari sungai di dekat daerah mereka untuk dialirkan ke petak-petak sawah. Usaha ini disebut dengan pompanisasi, yang menggunakan mesin diesel sebagai tenaga penyedot air.

Pompanisasi ini efektif digunakan ketika air di saluran irigasi benar-benar surut. Masalahnya biaya operasional yang dikeluarkan untuk usaha ini terlalu tinggi sehingga hal ini dapat mengurangi keuntungan petani. Selain itu juga, kekuatan pompa yang dimiliki Mitra cai ini tidak mampu mengairi seluruh areal persawahan di Dusun Leles, karena air lebih dulu terserap kedalam tanah sebelum mengairi seluruh areal persawahan. Blok Cigula sebagai daerah paling jauh dari pompa air sering kali tidak mendapat aliran air dari pompanisasi ini.

\section{KESIMPULAN}

Dalam penelitian ini air irigasi menjadi sebuah sumber daya yang merupakan commom property, sehingga pemakaiannya harus diatur agar seluruh pengguna dapat merasakan manfaatnya. Air bagi petani merupakan faktor penting dalam keberhasilan pertanian mereka. Padi tidak akan tumbuh tanpa suplai air yang cukup. Tetapi air juga bisa menjadi petaka bagi petani ketika jumlahnya berlebih, air dapat membanjiri sawah-sawah mereka dan menghancurkan padi-padi mereka. Jadi keberadaan air sebagai faktor pendukung pertanian julahnya harus terjaga, dan untuk menjaga kestabilan pasokan air irigasi ini dibutuhkan suatu pengelolaan dan kerjasama antar petani agar suplai air irigasi stabil. Hal ini sejalan dengan pendapat Ostrom (2000) mengungkapkan bahwa persoalan tentang sumber daya air yang berkaitan dengan kualitas dan kuantitasnya 
harus menyadarkan semua pihak bahwa persoalan air perlu dikelola secara bersamasama dalam sebuah organisasi, dalam hal ini organisasi irigasi. Organisasi P3A/Mitra cai mengatur dan mengelola saluran irigasi dimasing-masing daerah/desa. Pengelolaan air irigasi ini membutuhkan kerjasama antara seluruh pengguna air irigasi dan seluruh P3A/Mitra cai yang ada di DI. Wanir yang tergabung dalam Gabungan P3A (GP3A Tirta Walatra) dengan mengaktifkan hubungan sosial dan jaringan sosial yang mereka miliki agar masalah pasokan air ini dapat terselesaikan.

Jika mengacu pada Wolf (1985:144) tentang koalisi-koalisi petani, petani di Dusun Leles melakukan koalisi antara orang-orang yang mempunyai banyak kepentingan yang sama (many stranded) yaitu ketersediaan air irigasi. Petani di Dusun Leles menggunakan P3A/Mitra cai "Harapan I" untuk menjamin ketersediaan air irigasi pada petak-petak sawah mereka. Ketika mereka berhadapan dengan pihak luar mereka saling bekerjasama dan tergabung dalam satu organisasi P3A/Mitra cai "Harapan I". Kerjasama ini didasari oleh kesamaan kebutuhan, tujuan dan teritorial atau wilayah mereka.

Dalam memenuhi kebutuhan air irigasi ternyata petani tidak hanya menggunakan mitra cai sebagai sarana untuk menjamin ketersediaan air irigasi. ditemukan bahwa petani juga mengaktifkan hubungan-hubungan kekerabatan mereka untuk menjamin ketersediaan air dan produktifitas pertanian mereka. Mereka saling bekerjasama dari mulai pembajakan sawah, pemenuhan kebutuhan air, hingga proses pemanenan. Bentuk koalisi yang dilakukan P3A/Mitra cai dan keluarga ternyata memiliki perbedaan. Dalam kasus keluarga, koalisi mereka bersifat single stranded polyadik-horizontal, artinya mereka memiliki kepentingan yang sama terhadap keberhasilan pertanian. Koalisi ini meliputi banyak orang dan mereka juga memiliki kesamaan dalam status dengan ikatan keluarga. Koalisi ini bersifat langgeng. Sedangkan hubungan kerjasama yang dilakukan P3A/ Mitra cai "Harapan I" bersifat koalisi single strandedpolyadik-vertikal, yang artinya mereka memiliki satu tujuan dalam pengelolaan irigasi yaitu ketersediaan air irigasi, tetapi adanya perbedaan dalam status. Kedudukan pengurus lebih tinggi dibandingkan angota-anggotanya. Koalisi ini bersifat tidak langgeng. Sehingga ketika musim hujan dimana petani tidak membutuhkan air hasil nganir cai ataupun pompanisasi hubungan mereka menjadi rapuh.

\section{DAFTAR PUSTAKA}

Abdullah, Irwan. 2004. Pengembangan Sumberdaya Sosial di Daerah; dalam Dinamika Kependudukan dan Kebijakan (editor: Faturochman dkk). Yogyakarta: Pusat Studi Kependudukan dan Kebijakan Universitas Gadjah Mada, hal 177-196.

Benda-Beckmann, Franz von, dan Keebet von Benda-Beckmann. 2001. Jaminan Sosial, Sumberdaya Alam, dan Kompleksitas Hukum; dalam Sumberdaya Alam dan Jaminan Sosial Sosial (editor: F. Von Benda-Beckmann dkk). Yogyakarta: Pustaka Pelajar, hlm 23-60.

Bromley, D.W., and Cernea, M. M. 1989. The Management of Common Property Natural Resources: Some Conceptual and Operational Fallacies. World Bank Discussion Paper No.57, The World Bank, Washington,. DC.

Cousin, Ben. 1995. A Role for Common Property Institutions in Land Redistribution Programmes in South Africa. International Institute For Environment and Development: Gatekeeper Series No. 53.

Geertz, Clifford. 1983. Involusi Pertanian: Proses perubahan Ekologi di Indonesia. Jakarta: Bhratara Karya Aksara.

Hardjono, Joan. 1990. Tanah, Pekerjaan dan Nafkah di Pedesaan Jawa Barat. Yogyakarta: Gadjah Mada University Press.

Hutapea S.R dan Suzzane E, Siskel. 1996. Irigasi di Indonesia: Peran Masyarakat dan Penelitian Jakarta: LP3ES.

Krishna, Anirudh. 2000. Creating and Harnessing Social Capital; dalam Social Capital; Multifaceted Prespective. P. Dasgupta dan Ismail Serageldin (peny). Washington D.C. : The International Bank for Recontruction and Development/The World Bank.

Kurnia, Ganjar. 1997. Hemat Air Irigasi: Kebijaksanaan, Teknik, Pengelolaan, dan Sosial Budaya. Bandung: Pusat Dinamika Pembangunan. 
Koentjaraningrat. 1992. Beberapa Pokok Antropologi Sosial. Jakarta: Dian Rakyat.

Koning, Juliette. 1998. Akses Terhadap Tanah dan Air di Pedesaan Jawa;

PerananSumberdaya Alam dalam Jaminan Ekonomi dan Sosial. Dalam Sumber Daya Alam dan Jaminan Sosial, Editor Franz von Benda-Beckmann. Yogyakarta: Pustaka Pelajar. Mitchell, Bruce. 1989. Geography and Resource analysis. 2nd Edition
Singapore. Longman Scientific and Technical, hlm 2-6.

Siregar, Dr.Hadrian. 1981. Budidaya Tanaman Padi di Indonesia. Bogor: Satra Hudaya.

Wolf, Eric. 1985. Petani: Suatu Tinjauan Antropologi. Jakarta: Rajawali Pers dan Yayasan Ilmu-ilmu Sosial.

Buku Petunjuk Operasi dan Pemeliharaan Daerah Irigasi Wanir, Dinas Pengairan Kecamatan Ciparay.

Surat Kabar Republika, 23 desember 2014 dan 25 juli 2015 